Article

\title{
Responsible Research and Innovation: Using the Requirements Tool for Stakeholder Engagement in Developing a Universal Design for Learning Guidelines for Practice
}

\author{
Sara H. Wilford $\mathbb{D}$ \\ Centre for Computing and Social Responsibility, De Montfort University, G.H 5.77 Gateway House, \\ Leicester LE1 0BH, UK; sara@dmu.ac.uk
}

Received: 20 March 2019; Accepted: 19 April 2019; Published: 24 May 2019

\begin{abstract}
Responsible research and innovation (RRI) is growing in importance, and alongside this growth is an acknowledgement that for research and innovation projects to be successful, stakeholders must be involved from the outset. When developing guidelines for practice, stakeholders will often be presented with a document to ratify rather than one to develop or revise. This gap in stakeholder engagement has been recognised and addressed by the development of the requirements tool. This tool was originally created to provide a systematic approach to the development of guidelines for the governance of RRI, but it was quickly recognised that the tool can bridge the gap and involve stakeholders from the outset, thereby increasing the likelihood of buy-in. This paper presents the second validated use of the tool that was used to inform the revision of guidelines for the introduction of a universal design for learning (UDL) at a UK University. The resulting revised guidelines for practice and their adoption by those tasked with producing them provide further evidence of the value and flexibility of the tool and its potential for its continued use in the future development or revision of guidelines.
\end{abstract}

Keywords: responsible research and innovation; requirements gap; requirements tool guideline development; stakeholder engagement

\section{Introduction}

The concept of responsible research and innovation (RRI) as a discrete approach to research and innovation is relatively recent but has its roots in early 20th century discussions about 'value free' science and its dominance of social science thinking through the ideas of Max Weber. The idea that science, and social sciences in particular, should be conducted without a value judgements, and pay no concern to the potential consequences or outcomes, in the search of quantifiable truths. The potential dangerous and damaging nature of ethically neutral science [1,2], and its detachment from its stakeholders, has long been challenged [3-5] alongside concerns about ethics and the importance of involvement in the decision-making of those likely to be affected.

This has led to a relatively recent acknowledgement within the science community that 'The approach used by normal science to manage complex social and biophysical systems as if they were simple scientific exercises has brought us to our present mixture of intellectual triumph and socio-ecological peril' [6] and so science and innovation actors can no longer avoid responsibility for their activities as being necessary for science to be considered rigorous and therefore valid [7-10]. As scientific endeavours reveal ever greater complexity and interconnected dependencies, not including context, engaging with stakeholders, whether human or otherwise, and involving other external actors where possible, is actually irresponsible, unsustainable, and likely to result in poor science. This 
is particularly the case if those elements are not then factored into the policy and decision-making resulting from that science [10]. Therefore 'socially engaged and socially responsible' endeavours in science and innovation [11], and those involving stakeholders [12] at all stages, are critical to understanding and, therefore, acting sustainably across all types of endeavours from mining and industry $[13,14]$ to changes in organisational procedures or management practice [15].

RRI, with its emphasis on engagement, seeks to resolve these concerns; the concepts and frameworks of RRI are now being acknowledged and increasing in importance [6-8] in academia and policymaking and making some headway in industry [16-18]. RRI is a social construct and 'articulates entities and relationships that can potentially lead to desirable research results for social needs and goals (for whom and why) as well as for markets' [19]. Outcomes are achieved through 'mutually responsive processes of interaction between societal actors and innovators which take into account ethical acceptability, sustainability and societal desirability' [20]. Further, Owen considers future generations as being a key area of concern for RRI as 'responsible innovation is a collective commitment of care for the future through responsive stewardship of science and innovation in the present' [21], which clearly considers the necessity for sustainable science and innovation $[4,7,22]$. In this way, RRI stakeholder's engagement, and involvement in inclusive engagement in decision-making, helps to address the UN's sustainable development goals16 [23] and 17 [24].

Further, RRI considers that responsibility is personal and organizational, as well as local and global, by trying to address grand challenges, such as stewardship for future generations [21], and the responsibility of industry to work with civil society. In this way, the aim is to develop 'a transparent, interactive process by which societal actors and innovators become mutually responsive to each other with a view to the (ethical) acceptability, sustainability and societal desirability of the innovation process and its marketable products' [20].

The 'social license to operate' [25], which originated in the mining sector and is being adopted in other sectors, such as forestry [26] energy [27], involves engaging and negotiating with local communities regarding the costs and benefits of industrial development, [28] and is, therefore, compatible with and complimentary to an RRI approach. There are growing concerns about irresponsible innovation [29] and the resulting societal costs [30] with the impact of reaching across all industries and communities [31,32]. RRI, however, is a concept that can serve as an umbrella term to bring together a wide range of concepts and ideas. RRI also aims to embed ethics and responsibility into the development of new technologies and industry, and encourage organisational or societal change [32,33].

RRI principles, therefore, have been developed and adopted by a range of funding institutions. they are a pillar of the European Union (EU) Framework Programme for Research and Innovation-Horizon 2020 [34], and the AREA framework approach [21], which considers that innovators should anticipate, reflect, engage, and act to guide research and innovation, has been adopted by the Engineering and Physical Research Council in the UK [35]. However, from whichever perspective one considers utilising RRI, it can generally be agreed that its aim is to 'achieve acceptable and societally desirable outcomes of R\&I' [20].

RRI is constantly evolving and changing, which evidences its efficacy within the research community continues to grow and the body of literature that directly addresses RRI increases [36]. Amongst the aims for promoting further embedding of RRI into everyday practice is to provide tools that enable researchers, practitioners, and decision-makers to include RRI principles into their approach when undertaking organisational change. As such, tools and techniques have been developed to help practitioners achieve the practical application of RRI across many different sectors of endeavour [37].

This paper describes the practical use of an RRI approach to a change initiative at a UK University. In particular, this study presents and validates a requirements tool developed during a 7th Framework Programme for EU research (FP7) FP7 EU project, the governance of responsible innovation [38]. The requirements tool which resulted from that project, and was used to develop guidelines for RRI, is presented here as being utilised in a different context. 
De Montfort University (DMU) introduced the principles of universal design for learning into their teaching and learning activities in 2016 [39]. The initiative aimed at addressing some of the funding gaps created when the British government [40] removed disability funding. This initiative also aimed to provide a more inclusive and flexible approach to teaching and learning (universal design for learning, UDL) for students [41]. As part of the project, a set of guides were produced to help lecturers and those developing curricula to embed the principles of UDL into their activities and approach. These guides were produced with no stakeholder involvement and were not widely accepted as having relevance to particular subject areas by staff. The requirements tool that had been used in the project 'Governance for Responsible Innovation' (GREAT) to create guidelines was utilised to revise the guides for UDL practice so that they were designed by those asked to use them, with direct relevance to their own particular area of expertise.

Applying the requirements tool within this organisational change context would also provide evidence of the flexibility and potential for further practical application of the requirements tool across different sectors and in different contexts.

In the following sections, I will first present the underlying philosophy of RRI adopted by the GREAT project, notwithstanding the historical and complimentary aspects of Science and Technology Studies, Corporate Social Responsibility and the social license to operate, highlighted above. It explains how understanding of the literature underpinned the approach to the development of the requirements tool and, subsequently, the guidelines for RRI. Next, the requirements gap is discussed, which explains how the lack of engagement early in the process of change may lead to ineffective or subsequent failure of new initiatives, and how identification of this gap highlighted that, for an RRI project to utilise RRI in practice, a solution to this gap needed to be developed. This paper then goes on to explain the process of development and the outcomes of the resulting guidelines being used in practice. The next section explains the rationale for utilising the requirements tool as part of a review of existing guidelines within the context of organisational change and the introduction of the universal design for learning at a UK University. Details of the process and use of the tool are provided, and the outcomes presented. Finally, there is a discussion of the future potential to embed RRI into organisational change initiatives and how the use of the requirements tool can help in achieving UN sustainable development goals 16 and $17[23,24]$ and to increase the likelihood of successful adoption of new innovations and initiatives in industry, education, and beyond, through greater and earlier stakeholder engagement.

In order to understand the philosophical and theoretical landscape of RRI and the discourse between science and society the GREAT project undertook a Horizon scanning literature review in 2013 [42], alongside a further review of the theory and philosophical underpinnings of RRI thinking through to 2016 [43], to paint a theoretical landscape of RRI. Through this work, five key ingredients of RRI, which were largely inclusive of RRI thinking at the time, were identified:

- Anticipation - which tries to predict societal impact from technological development,

- Transparency - to guarantee openness to include dissemination and discussion of all outcomes.

- Responsiveness-to be willing and able to act to adapt and revise practice, procedure and behaviour as circumstances and needs change.

- Reflexivity-Two orders of reflexivity include considering how far something could be adapted or changed to improve outcomes and to acknowledge how researchers are framing their work and the assumptions and unconscious bias that may affect their decisions.

- Participation — ensures that all stakeholders should be engaged in meaningful involvement from the outset and throughout a project.

This work informed the entire philosophical approach for the project and, by extension, the process by which the identification of the requirements for RRI guidelines would be developed. To produce the guidelines themselves, however, involved further understanding of how they could, alongside other training and development activities, lead to new and more responsible behaviours becoming normalized in practice. 
It is clearly important that any new set of guidelines, rules, or new procedures should be informed by the context in which they would be applied [44]. In this way, a transition is more likely to be achieved so that new norms and ways of working become tacitly embedded into everyday practice and are less likely to be subject to resistance by workers. As part of this approach, [45] explains the need for reflexivity and for 'doing' RRI; the author explains that 'engagement with ethical questions will require the development of reflective processes within research, so that norms, their context and application can be understood, predicted and influenced'. Further, perceptions of effective governance identify a need to resolve the conflicts between 'scientific accuracy, policy effectiveness and political legitimacy' [46] in order to be successfully embedded in everyday working, but fail to recognise the requirement for acceptance and user adoption of any new initiatives. For effective governance in any sphere, it seems only sensible to include those being governed, and expected to adopt organisational change in their daily lives, in the entire development process. Whilst there is some reluctance to adopt RRI in healthcare due to concerns about patient involvement [47], there is some evidence of its adoption in science education $[37,48]$.

RRI requires that there is due consideration of the impact of organisational change on individuals and smaller groups, such as those within and between those organisations or teams that are at the forefront of such change [49] The introduction of new processes and procedures, therefore, can have a huge impact on those both directly and indirectly affected by them and if they are done without due diligence, involvement, and reflection [50,51]; then, these processes and procedures are unlikely to be fully effective, or may result in unexpected negative outcomes.

\section{Rationale and Methods}

\subsection{The Requirements Gap}

When creating guidelines for any purpose, where there is stakeholder engagement, it invariably involves the inclusion of those stakeholders at some point. The necessity to include stakeholders in decision-making is well-established $[49,50,52,53]$. The inclusion of stakeholders into the analysis of the impact of industry in local areas [54] and the need to involve patients in decision-making [55] provide good examples of where stakeholder engagement is both important and necessary. However, particularly where there are internal organisational changes or new innovations, it can be the case that new initiatives, such as guidelines for practice, do not get to the stakeholder engagement phase until they have already been developed. Unless there are serious objections, it is expected at this stage to only require tweaks and minor changes before the new initiative can be rolled out to all. The stakeholders in this case are rarely involved in the creation of the original guidelines and are highly unlikely to be asked what they would like to see in the guidelines from the outset, or how they could be made to be useful and relevant.

This gap means that the stakeholder requirements for those guidelines have already been decided upon by those creating them, thereby severely limiting the options stakeholders have to shape those guidelines in such a way that they are fit for purpose from the outset [56]. This lack of stakeholder consultation and inclusion at the design phase of guidelines creation means that it is then much more difficult for organisations to know if what is being provided to stakeholders [22] and if it is what they would have wanted or found helpful, had they been asked in the first place. It is understood that when there is limited time or existing documents, then stakeholders may be presented with a draft, but the key to addressing the gap is to provide the opportunity for stakeholders to rip it up and start again.

\subsection{The Requirements Tool}

To address this engagement gap, the requirements tool was developed (see Appendix A) and subsequently validated in practice to enable RRI principles to be included in developing guidelines and recommendations $[50,56]$. The tool was developed to identify what the stakeholder's requirements were, before going on to develop the guidelines themselves. Utilising RRI principles in the development 
of the tool itself, through stakeholder engagement from the outset, meant that the participants were involved at all stages of the development of the requirements tool, which in-turn led to the identification of the requirements for the resulting guidelines for RRI [57].

The requirements tool was developed during an EU project tasked with understanding and driving the governance of RRI, which included the production of a set of guidelines for practice informed by a strong theoretical base [43]. The aim was to 'develop an empirically based and theoretically sound model of the role of responsible research and innovation governance' [38] and bring about new and more responsible norms of behaviour in research and innovation and to provide researchers with guidelines to help them to implement RRI into their working practices.

The guidelines aimed to clarify and provide practical answers to RRI that could then be incorporated into both the process and outcomes of research and innovation projects. However, once the team started to directly engage with the process of developing guidelines, utilising a 'practice what you preach' RRI approach, it soon became apparent that there was a disconnection between those being provided with guidelines and the production of those guidelines. A key element of RRI is engagement [21,58], so those most likely to be expected to use the guidelines were invited to provide input into what kind of things should and should not be included, what format would be most helpful, and so on. The process of engagement to discover the requirements for guidelines led to the development of the requirements tool [59]. The guidelines for RRI resulting from the use of the tool have successfully been applied in several key EU projects $[60,61]$ and are further presented in use within the context of organisational change.

The tool, in the form of a table, works by asking questions regarding general requirements, content specific requirements, those specific to the project, areas of enquiry or stakeholder groups, and issues and concerns that need to be addressed prior to the development of guidelines. In this way, the tool provides a reflective, robust and flexible approach to the development of guidelines or to changing processes within an organisation. The expectation of reflexivity that is built into the tool helps people to understand how guidelines for a research or innovation project or a change to working practices should be structured and what those guidelines should contain to achieve desirable outcomes for that particular project or initiative.

It was recognised quite early on in the development process, and from its application in practice, that the requirements tool could be useful, not only for RRI guidelines, but also for stakeholder engagement activities across all sectors and disciplines. At a minimum, however, the requirements tool in practice led to an understanding that when a set of guidelines are required, the discipline in which those guidelines are used, is of less importance than the effectiveness and perceived usefulness of the guidelines themselves $[56,57,62]$.

\subsection{A Guide for Universal Design for Learning}

The opportunity to test the tool and its flexibility to apply it in a different context came about during the implementation of a University-wide project to embed universal design for learning (UDL) principles into teaching and learning practice. UDL is a flexible approach that encourages universal access to resources, assessment and services which encompasses the needs of all students, including those with disabilities, and supports the student's learning throughout their course [63]. The aim is to level opportunities rather than merely providing specialist provision $[41,64]$.

The University decided to adopt a new approach to teaching and learning in order to better support all their students. As a potentially far reaching and innovative organisational change to teaching and learning practice, the University was keen to ensure that all staff engaged with the process of that change [65].

UDL Champions, including the author of this paper, were seconded from each faculty to support staff in implementing the new requirements, and a series of workshops and training sessions introduced staff to the key aspects of UDL and how it would impact on their curriculum development. Examples included recording lectures, providing materials in a range of different formats, devising flexible, student 
centred assessments, and so on. In addition, as part of the process of embedding UDL practices into curriculum development within the University and the provision of learning opportunities for students, a set of guidelines including advice on how to apply them, were developed and distributed to staff.

The faculty is diverse and wide-ranging with three schools offering different teaching and learning experiences for their students from journalism to cyber-security, computer science to mechanical engineering. The main rationale for introducing UDL across the whole University was to widen student access to teaching and learning tools and resources, and thereby improve outcomes for all students [66]. The UDL approach is flexible and inclusive enough to accommodate all learning styles and learning differences by removing barriers rather than providing alternative provision [67]. Therefore, it was anticipated that this would improve student outcomes.

As the UDL champion for the faculty of Technology, the author was required to undertake a number of training and development workshops to promote UDL and to help people include the principles into their teaching practice. This process also provided an opportunity to informally gain feedback on the guidelines that had already been developed. Although largely anecdotal, it quickly became apparent that the guides were only generally useful and lacked direct discipline specific relevance. Further, it was also apparent that a failure to engage with the guides that were provided to facilitate this organisational transformation could mean that it would be more difficult to achieve the desired outcomes of embedding UDL into everyday teaching and learning practice. In light of the feedback received therefore, permission was gained to re-shape and tailor the guidelines to each of the schools within the faculty.

This also provided an opportunity to test the flexibility of the requirements tool to improve an existing set of guidelines, (as previously it had only been used to identify requirements for a new set of guidelines), and to utilise an RRI approach in the process by engaging with the stakeholders in a co-creation exercise from the outset.

The task would result in either a complete re-making or at least a revision of the guides for UDL that focus on the specific needs of each of the schools. An RRI approach was taken from the outset, and the AREA framework was adopted to systematically ensure that an ethos of RRI was embedded into the project throughout.

\subsection{Identifying and Engaging with Participants}

The target group for participants in the project were those within each school who were in positions that not only would require them to undertake curriculum development activities themselves, but also might be supporting other staff in their teaching development. Within each of the three schools these participants are further sub-divided into four subject groups, so an email was sent to each subject group leader asking for nominations of 1-2 people to be invited to be involved in the project. From this process of nomination and invitation, 6 participants volunteered from two of the schools, and 8 from the third, one of whom left the project after one meeting.

Participants comprised:

- 1 Full Professor

- 4 Associate Professors

- 6 Senior Lecturers

- 7 Full time Lecturers

- 1 Part time Lecturer

It was fortunate that there was a good range of staff members across each of the schools, as well as a mix of senior and junior staff, included in the project. All participants were directly affected by the requirements of UDL and would need to use the guidelines. All of the volunteer staff had undergone some UDL training and were keen to utilise the principles in their teaching and learning activities, hence their agreement to be involved. This meant that these stakeholders were particularly well-placed to engage with and value the aims of the project. 


\subsection{Workshops}

The workshops were designed to provide an opportunity for affected staff to make the decisions about what should be included in the revised guidelines for UDL in each school in the faculty. The stakeholders were, therefore, engaged with the process and were informed from the outset that, if they wished, they could completely reject the guidelines and work to create a new set of guidelines. The participants were all happy to revise rather than start from scratch. It may be that the prospect of creating a new set of guidelines would have involved more time and commitment than they were able to commit; thus, the existing guidelines were to be revised rather than replaced, but that was the decision of the participants.

Thematic analysis was used to identify key themes and issues, and where individuals gave feedback or provided perspectives that the other group members agreed with, those themes were also taken into account. The results of the analysis were then used to firstly adapt the requirements tool to a project specific focus, and then to use the tool to analyse and identify changes in the guidelines.

\subsubsection{Workshop 1-Adapting the Requirements Tool}

The first workshop included all of the volunteers for the project as the aim was to adapt the requirements tool to replace RRI with UDL approaches, which would then be used to guide the re-creation of the guidelines that were school specific in a subsequent workshop.

When validating a tool, it would normally be presented ready for use by stakeholders. However, the core principle of the tool, its development, and its validity is the engagement process being at the outset. So, involvement of stakeholders in framing and adapting the requirements tool is the first step in its use to bridge the requirements gap. This meant that when using the revised requirements tool, participants were already invested in its usefulness to revise the guidelines.

Each participant was sent a copy of the original requirements tool two weeks before the workshop with information regarding how it had been developed and used in the GREAT project. They were also provided with information about the aims of the workshop and advised about how they could reflect upon the tool and how it could be adapted so that it could be used to re-develop the guidelines for UDL. Copies of the existing guides for UDL were also sent to all participants. Consent forms were also provided for participants to sign before the workshop.

The workshop specifically intended to make direct changes to the tool, not just to gain feedback so that existing tool was re-purposed to aid in the revision of the guidelines for UDL. At the start of the workshop, the organiser explained the purpose of the tool and asked each participant to briefly give their own perspectives on the tool and the UDL guides. Then, in informal, tabled groups, they were asked to further reflect on, discuss, and review the existing tool, and to identify changes that would help guide them towards school specific revisions. After $20 \mathrm{~min}$ of group discussion, each group was asked to present their conclusions. This process was followed by a full group discussion for $10 \mathrm{~min}$, where the changes to the tool were agreed upon.

The resulting revisions were sent to participants, resulting in the revised requirements tool (Table 1 below), which would then be used in the project to guide the revision of the UDL guidelines.

Table 1. Requirements tool for Universal Design for Learning (UDL).

\begin{tabular}{|c|c|c|c|}
\hline & General Requirements & $\begin{array}{l}\text { Requirements Specific to Project, } \\
\text { Area of Enquiry, Specialism or } \\
\text { Stakeholder Group }\end{array}$ & Issues and Concerns \\
\hline 1 & $\begin{array}{l}\text { Use a common language that overlaps } \\
\text { all disciplines within the school }\end{array}$ & $\begin{array}{l}\text { May require use of some technical } \\
\text { language (Glossary) for clarity } \\
\text { and precision. }\end{array}$ & $\begin{array}{c}\text { Over simplification or too much } \\
\text { technical language may result in } \\
\text { evasion of the 'spirit' of UDL } \\
\text { in practice }\end{array}$ \\
\hline
\end{tabular}


Table 1. Cont.

\begin{tabular}{|c|c|c|c|}
\hline & General Requirements & $\begin{array}{l}\text { Requirements Specific to Project, } \\
\text { Area of Enquiry, Specialism or } \\
\text { Stakeholder Group }\end{array}$ & Issues and Concerns \\
\hline 2 & $\begin{array}{l}\text { Be concise and ensure it is practical and } \\
\text { usable (bullet points, etc.). Shorter } \\
\text { documents are more likely to be read } \\
\text { and understood. }\end{array}$ & $\begin{array}{l}\text { Some schools may need detailed } \\
\text { descriptions to ensure value } \\
\text { and relevance. }\end{array}$ & $\begin{array}{l}\text { Too brief may lead to lack } \\
\text { of clarity }\end{array}$ \\
\hline 3 & $\begin{array}{l}\text { Use good style to enhance readability } \\
\text { (colours, diagrams, pictures, etc.) } \\
\text { Attractive and easy to understand }\end{array}$ & & $\begin{array}{l}\text { Could trivialise or over complicate } \\
\text { the message }\end{array}$ \\
\hline 4 & $\begin{array}{l}\text { Provide an interactive document } \\
\text { (e.g., links to UDL websites, case } \\
\text { studies, examples of good/bad practice, } \\
\text { tools and resources) }\end{array}$ & $\begin{array}{l}\text { To inform from the perspective of } \\
\text { the specialism of the school. } \\
\text { Provide access to multiple sources } \\
\text { and perspectives, provide } \\
\text { contextualised approach }\end{array}$ & $\begin{array}{l}\text { Information overload and } \\
\text { accessibility issues }\end{array}$ \\
\hline \multicolumn{4}{|c|}{ Content Related Requirements } \\
\hline 5 & $\begin{array}{l}\text { Provide a range of UDL Definitions to } \\
\text { broaden awareness of UDL principles } \\
\text { and to encourage the use of UDL theory } \\
\text { to relate to practice. }\end{array}$ & & $\begin{array}{l}\text { Perspectives included in } \\
\text { definitions may be limited or } \\
\text { narrow, or, conversely, } \\
\text { information overload may } \\
\text { create confusion. }\end{array}$ \\
\hline 6 & $\begin{array}{l}\text { Comment on UDL Definitions- } \\
\text { description, scope, and complexity }\end{array}$ & & $\begin{array}{l}\text { Interpretive and limited, possible } \\
\text { narrowing of perspectives }\end{array}$ \\
\hline 7 & $\begin{array}{l}\text { Include case studies_-Bad' practices or } \\
\text { normative dilemmas to provide } \\
\text { examples for discussion. }\end{array}$ & & $\begin{array}{c}\text { Case studies may be limited or not } \\
\text { sufficiently relevant }\end{array}$ \\
\hline 8 & $\begin{array}{l}\text { Include case studies-'Best' practices to } \\
\text { provide examples for discussion. }\end{array}$ & & $\begin{array}{c}\text { Case studies may be limited or not } \\
\text { sufficiently relevant }\end{array}$ \\
\hline 9 & $\begin{array}{l}\text { Include UDL tools-to provide } \\
\text { examples for discussion leading to } \\
\text { organisational/individual learning }\end{array}$ & & $\begin{array}{l}\text { Tools may not be useful } \\
\text { or relevant }\end{array}$ \\
\hline 10 & $\begin{array}{l}\text { Acknowledge that tools and case } \\
\text { studies provided may not always be } \\
\text { relevant and should be adaptable to } \\
\text { encourage stakeholders to produce new } \\
\text { approaches based on their own } \\
\text { experience and expertise }\end{array}$ & & $\begin{array}{l}\text { If too flexible, may have little } \\
\text { impact as too weak to be effective }\end{array}$ \\
\hline 11 & $\begin{array}{l}\text { Respond to DMU teaching and learning } \\
\text { policy and the strategic plan }\end{array}$ & $\begin{array}{l}\text { Identify and respond to aspects of } \\
\text { DMU policy that are specific to } \\
\text { implementation of UDL }\end{array}$ & $\begin{array}{l}\text { May be too prescriptive. May not } \\
\text { be accepted in other geographical } \\
\text { regions. May narrow scope and } \\
\text { constrain innovation or may create } \\
\text { confusion due to contradictions. }\end{array}$ \\
\hline 12 & $\begin{array}{l}\text { Use empirical analysis to inform } \\
\text { development of guidelines. Avoid } \\
\text { uncritical approaches and to facilitate } \\
\text { specific development across the school. } \\
\text { Provide background understanding of } \\
\text { the needs of the school }\end{array}$ & & $\begin{array}{l}\text { Limited scope could cause } \\
\text { narrowing of perspectives }\end{array}$ \\
\hline 13 & $\begin{array}{l}\text { Provide information and explanations } \\
\text { on existing UDL approaches and } \\
\text { resources including web links } \\
\text { and references }\end{array}$ & $\begin{array}{l}\text { Facilitate awareness and } \\
\text { understanding of school } \\
\text { specific approaches }\end{array}$ & $\begin{array}{l}\text { Existing approaches may be } \\
\text { limited or too complex } \\
\text { or unsuitable }\end{array}$ \\
\hline
\end{tabular}

\subsubsection{Workshop 2-Revising the guidelines}

The aim of each of the school specific workshops was to identify the changes that were required to make the guides more effective by using the UDL requirements tool to guide the decision-making process. The tool enabled a systematic and focused approach to identify what was needed and how it should be presented. In all workshops, the original look and feel of the guides was retained, as they were felt to be easy to understand; the guides contained a checklist and other easy to use sections. 
The main complaint from the participants was the generic nature of the content and the lack of consultation and involvement in their creation.

During the sessions, the participants emphasised the importance of incorporating teaching and learning practices of the specific subject area into the guidelines for UDL. In addition, within the generic guides, some explanations were provided, but it was felt that they needed improvement.

The workshops for revisions of the guidelines involved a smaller number of participants, as these were done with just the members of each school. The participants were asked to provide their initial perspectives before being split into two groups to consider how to revise the guides. The requirements tool was used to guide and structure their deliberations and to help them to provide concrete changes. The resulting requirements from the participants were written on flip-charts. After $15 \mathrm{~min}$, the charts were exchanged and the perspectives re-examined, revised, and added to. Finally, the whole group discussed and reflected on the ideas presented, to identify gaps and duplications, as well as any ideas that were subsequently rejected or retained.

During this discussion, it was also recognised that often the teaching staff were already including UDL into their curriculum development, but were not always able to identify it as such. By making the UDL guides and their accompanying notes specific to the subject areas, it would become much easier for staff to identify what was meant by the term UDL when applied to their experiences of teaching engineering, journalism, or computing, and to recognise that what they were doing was already incorporating a UDL approach.

\section{Results, Outcomes and Outputs}

\subsection{Review and Inclusion of New Requirements into Existing Guidelines}

Discussion regarding the original guides strongly indicated that whilst the guides were easy to follow due to their relative simplicity, they were also highly generic, overly prescriptive, and in some cases, not relevant, which meant that they lacked guidance and were more useful as a very basic checklist.

The researcher then collected all of the notes and flip charts from the sessions and converted then to a word document. This document was then analysed to identify the ideas, requirements, and perspectives of the participants. These findings then informed the changes to the guides to make them more specific to the subject area in which they were to be used.

The revised guides for each school had a cleaner, simpler format. Additional information and access to resources and links were now provided in a separate guidance notes document. Participants had expressed concern about the examples provided in the guides that were unclear, not relevant to them, or overly prescriptive. Stripping out much of this problematic material to present the content in a more detailed information document which included links to further resources meant that the guides themselves could act as tools to support incorporating UDL, and the guidance notes provided helpful examples and advice. This document included many of the more detailed requirements identified through the use of the requirements tool, such as links to further information and sources of other UDL tools, and techniques, all of which meant that the new set of documents retained their original simplicity, whilst providing access to greater detail if required.

The resulting guides and explanatory notes were then sent to the workshop participants for further review and feedback. This led to some minor revisions and the addition of case study examples to the supporting document. After the second round of changes were made, no further changes were requested by the participants, and approval for the final versions was obtained. The resulting guidelines and explanatory notes were then sent to each head of school to be distributed to all staff involved in curriculum, module, or programme planning to aid their future adoption of UDL in their teaching and learning. 
Feedback from the participants regarding the process and outcomes indicated that not only were the guides now perceived to be much more useful, particularly for those who were new to curriculum development, but participants indicated they had found both the process and the tool to be helpful to enable them to focus their activities and to feel genuinely part of the process.

Whilst it is clear that when undergoing change, the inclusion of stakeholders is important, within an academic environment, where there is a high level of expertise and professional integrity, it can be argued that managers and professors are not always utilising the existing resources at their disposal. The process of revising the guidelines and the subsequent feedback from participants illuminated the value of both the tool and the engagement process.

\subsection{The Requirements Tool in Practice}

The requirements tool has now been used in two practical examples. In the first, a new set of guidelines for RRI was developed. The requirements tool was devised to close the stakeholder engagement gap in an RRI project, by helping to identify what those who would use a set of guidelines for the governance of RRI would need in those guidelines in order for them to be effective. The resulting guidelines from that process have been successfully adopted within a number of RRI related projects. The second practical example of the use of the requirements tool is provided by the UDL case, whereby the requirements tool demonstrated its flexibility. The tool was adapted according to the area in which it was to be applied, i.e., UDL, and then used to guide the next step, involving the revision and tailoring of an existing set of guides to make them more appropriate to those to which they would be applied [56]. The common factor in the successful development of the guides is the bridging of the stakeholder requirements gap.

That the speed that the tool can be adopted and adapted for specific needs makes it highly usable, particularly if guidelines are already in existence, and revision is needed urgently to avoid disengagement by stakeholders, if, for example, there is disillusionment about the first set of guidelines. The tool, because its core parameters are already in place, can be adapted quickly, with the insertion of indicative words in key areas as a starting point, to be then adapted further if required during the initial stakeholder engagement process.

While there is still significant work to do to further validate the requirements tool, the evidence is growing that this tool can be useful to bridge the stakeholder requirements gap, something that has been largely neglected when developing guidelines for practice and when undertaking organisational or social change. In fact, it could be surmised that this gap has not been previously identified in the literature. The adaptation and adoption of the tool in research and innovation and within industry would strengthen engagement by involving stakeholders much earlier in the research process. For example, in industry, to obtain a 'social licence to operate' [26], or to undertake mining operations, local communities would be engaged at the initial concept stage so that the most important concerns and assurances can be identified and addressed earlier. In this way, communities are able to directly influence local industrial development thereby minimising opposition and building relationships [27] Within research and innovation projects, the wants, needs, and concerns of stakeholders can be better understood $[22,36,50,54]$ rather than assumed or imposed, thereby avoiding the development of inappropriate or useless artefacts, imposing unworkable policy, or devising unsatisfactory working practices.

The experience of revising the guides for UDL also highlighted further uses for the tool in an educational environment. Student engagement, experience, and active involvement in the development of their courses is growing, with feedback at all levels being elicited from students, who in turn inform curriculum development. The flexibility of the requirements tool means that it could also be used to engage with students so that courses are developed that reflect their needs or changes in learning styles, whilst at the same time enabling students to know that their input is having a direct impact on the way that their courses are developed. 
One of the core principles of RRI is reflexivity, or the ability to consider not only the context in which a decision is made, but also the pre-conceived ideas, world view, and personal context of the decision-makers. The requirements tool provides an opportunity for open dialogue, with the objectives clearly defined but is flexible and adaptable to any situation requiring change. By providing the initial topics for reflection and discussion, the tool avoids some of the potential conflicts that may arise. The likelihood of success is dependent on the buy-in of those tasked to implement or who will be affected by it, and the progress is being aimed globally, with initiatives such as the UN sustainable development goals, proposing early and democratic involvement of stakeholders [18], and the requirements tool provides a first step in linking the needs of people to the needs of future research, innovation, and development.

However, sometimes there is a perception from management and those in disciplines where 'value free' approaches remain dominant [4], that issues of concern raised are actually just pushing back against change or progress. The requirements tool enables important discussions around management of change or the conduct of research and innovation to be had, and to turn the process into one that involves stakeholders being part of the decision-making process [12] and avoids the formation of negative perceptions. The reflective and transparent nature of the tool also increases the likelihood of the adoption of new approaches, guidelines, and practices by those who have been involved in their development.

There is a push towards introducing and developing RRI and better governance of science [68] across all sectors, from industry to academia, and from the public to the private. The development of tools to aid organisations across disciplines to adopt RRI in ways that provide positive outcomes is a valuable aim. For example, researchers [16] have developed a maturity model that helps industries to assess their readiness and ability to incorporate RRI into their Research and innovation processes, and thereby provide insight and goals for industry. The requirements tool is still in its infancy with regards to its use in practice, and so taking opportunities to test its practical application and flexibility will benefit not only the stakeholders engaged in guidelines development but will also add to the ever growing toolkit towards the adoption of RRI.

Funding: This research received no external funding.

Acknowledgments: Thanks to De Montfort University for their support in conducting this research.

Conflicts of Interest: The author declares no conflict of interest.

\section{Appendix A}

\section{Appendix A.1. Requirements Tool Development Process}

In order to develop an effective tool, it was important initially to examine how guidelines were being created elsewhere, and to evaluate the effectiveness of their approach.

In the first instance, therefore, all of the publicly available documentation from two large multi-disciplinary projects that had included the development of guidelines in their deliverables, were examined in detail. The projects were selected due to their direct relevance to both RRI and the production of guidelines, and represented key projects from two research funding bodies. CONSIDER (Civil Society Organisations in Designing Research Governance) was a European Commission (EC) FP7 project that had created a set of stakeholder specific RRI guidelines for engagement with Civil Society organizations. Framework for Responsible Research and Innovation in Information and Communication Technologies (FRRICT), was a project funded by the EPSRC (Engineering and Physical Sciences Research Council), which had created a framework and tools for RRI in Information and communication technologies (ICT). Through the review of the approaches taken by these projects, it was possible to identify 14 outline proposals for requirements for guidelines that would act as the starting point for discussion with the stakeholders. 
Academics and researchers from a range of disciplines were invited to attend a workshop for the purposes of understanding and identifying the requirements for guidelines. The engagement process at the very beginning of the process was intended to help to bridge the requirements gap identified above. The process enabled the researchers to understand the particular context and needs to produce a set of guidelines, and the participants were able to shape the nature and scope of guidelines by identifying their own requirements from the outset.

The process also enabled both the participants and researchers to reflect on what was being created and the rationale for its creation, as well as being part of the creation process.

The workshop focused on problem-centred group discussions moderated by the researcher [62]. The discussion centred on reflecting on the initial set of 14 outline proposals, to provide their views and input. The participants were encouraged to be highly critical and reflexive throughout, to consider how their context specific needs could best be represented in a set of requirements at the same time as being asked to 'think about their own ethical, political or social assumptions underlying and shaping their roles and responsibilities in research and innovation as well as in public dialogue' [43], in a process involving two orders of reflexivity.

This meant that one of the most active discussions was around perceptions about having guidelines for RRI governance at all, and the need and likelihood of acceptance and adoption in a broader sense. This discussion highlighted a generally dismissive approach to the idea of guidelines in any form. It was acknowledged by the participants that this perception of guidelines was in-part due to previous experiences of guidelines being imposed with little or no consultation, which merely served to highlight the need to take a different approach. A more detailed description of the methodology used in the development of the requirements tool can be found in [50,56,59].

The table below provided the identification of requirements that enabled the development of guidelines for the governance of RRI [69]. These guidelines were validated by their adoption in the EU Horizon2020 project 'Progressive Standards in ICT for active and healthy ageing' (PROGRESSIVE) as its internal RRI guidelines document for its activities.

Table A1. Requirements tool for Responsible Research and Innovation (RRI).

\begin{tabular}{llll}
\hline \multicolumn{1}{c}{ General Requirements } & $\begin{array}{c}\text { Requirements Specific to Project, } \\
\text { Area of Enquiry, } \\
\text { or Stakeholder Group }\end{array}$ & \multicolumn{1}{c}{ Issues and Concerns } \\
\hline $1 \quad \begin{array}{l}\text { Use a common language that overlaps } \\
\text { all disciplines. }\end{array}$ & $\begin{array}{l}\text { May require use of some discipline } \\
\text { specific language (Glossary D2.1) } \\
\text { for clarity and precision. }\end{array}$ & $\begin{array}{l}\text { Over simplification or too much } \\
\text { complexity in the discipline } \\
\text { specific language may result } \\
\text { confusion or the evasion of the } \\
\text { 'spirit' of RRI in practice. }\end{array}$ \\
\hline $\begin{array}{l}\text { Be concise and ensure it is practical and } \\
\text { usable (bullet points etc.) Shorter } \\
\text { documents are more likely to be read } \\
\text { and understood. }\end{array}$ & $\begin{array}{l}\text { Some projects, areas of enquiry or or } \\
\text { stakeholder groups may need } \\
\text { detailed descriptions to ensure } \\
\text { value and relevance. }\end{array}$ & $\begin{array}{l}\text { If the guidelines are too brief they } \\
\text { may lead to lack of clarity } \\
\text { and detail. }\end{array}$ \\
\hline $\begin{array}{l}\text { Use good style to enhance readability } \\
\text { (colours, diagrams, pictures other types } \\
\text { of media). Make it attractive and easy } \\
\text { to understand. }\end{array}$ & & $\begin{array}{l}\text { Could trivialise or over complicate } \\
\text { the message. }\end{array}$ \\
\hline
\end{tabular}


Table A1. Cont.

\begin{tabular}{|c|c|c|c|}
\hline & General Requirements & $\begin{array}{c}\text { Requirements Specific to Project, } \\
\text { Area of Enquiry, } \\
\text { or Stakeholder Group }\end{array}$ & Issues and Concerns \\
\hline 4 & $\begin{array}{l}\text { Provide interactive document (e.g., } \\
\text { links to RRI websites, case studies, } \\
\text { examples of good/bad practice, tools } \\
\text { and resources). }\end{array}$ & $\begin{array}{l}\text { To inform from the specific project, } \\
\text { area of enquiry or stakeholder } \\
\text { group as well as more broadly. } \\
\text { Provide access to multiple sources } \\
\text { and perspectives and provide a } \\
\text { contextualised approach. }\end{array}$ & $\begin{array}{l}\text { Information overload and } \\
\text { accessibility issues. }\end{array}$ \\
\hline & \multicolumn{3}{|l|}{ Content Related Requirements } \\
\hline 5 & $\begin{array}{l}\text { Provide a pitch to grab attention for } \\
\text { example, a cover page with the } \\
\text { key points. }\end{array}$ & $\begin{array}{l}\text { Graphics and wording to aim at } \\
\text { specific target audience }\end{array}$ & $\begin{array}{l}\text { Tone may be inappropriate, over } \\
\text { simplification }\end{array}$ \\
\hline 6 & $\begin{array}{l}\text { Provide a single definition of RRI and } \\
\text { other key terms and provide a } \\
\text { description of meaning, scope, and } \\
\text { complexity within the document } \\
\text { through links to the Glossary (D2.1). }\end{array}$ & & $\begin{array}{l}\text { May be too narrow, overly } \\
\text { prescriptive, or irrelevant in } \\
\text { stakeholders' particular contexts }\end{array}$ \\
\hline 7 & $\begin{array}{l}\text { Provide links to different definitions of } \\
\text { RRI to broaden awareness of RRI } \\
\text { principles and to encourage the use of } \\
\text { RRI theory to relate to user's } \\
\text { own practice. }\end{array}$ & & $\begin{array}{l}\text { Perspectives included in } \\
\text { definitions may be limited or } \\
\text { conversely, information overload } \\
\text { may create confusion or possible } \\
\text { narrowing of perspectives. }\end{array}$ \\
\hline 8 & $\begin{array}{l}\text { Provide links to projects, case studies, } \\
\text { examples or normative dilemmas of } \\
\text { 'good' and 'bad' practices to provide } \\
\text { examples for discussion and to provide } \\
\text { relevance for specific } \\
\text { stakeholder groups. }\end{array}$ & & $\begin{array}{l}\text { Case studies may be limited or not } \\
\text { sufficiently relevant. }\end{array}$ \\
\hline 9 & $\begin{array}{l}\text { Provide links to RRI and governance } \\
\text { tools to provide information and } \\
\text { explanations on existing RRI } \\
\text { approaches and resources including } \\
\text { web links and references. This will } \\
\text { provide examples for discussion leading } \\
\text { to organisational/individual learning. }\end{array}$ & $\begin{array}{l}\text { Facilitate awareness and } \\
\text { understanding of domain specific } \\
\text { approaches e.g., FRRIICT } \\
\text { strengthens perception of the } \\
\text { legitimacy of the guidelines in ICT. }\end{array}$ & $\begin{array}{l}\text { Tools may not be useful or } \\
\text { relevant. May be confusing if too } \\
\text { many options are available. } \\
\text { Existing approaches may be } \\
\text { limited, too complex or unsuitable }\end{array}$ \\
\hline 10 & $\begin{array}{l}\text { Provide methods to re-asses and } \\
\text { challenge the guidelines including a } \\
\text { regular review. }\end{array}$ & & $\begin{array}{l}\text { If too flexible, may have little } \\
\text { impact as the guidelines may be } \\
\text { too weak to be effective. }\end{array}$ \\
\hline 11 & $\begin{array}{l}\text { Respond to EC framework, e.g., } \\
\text { intervention logic model (relevance, } \\
\text { effectiveness, efficiency, utility) and } \\
\text { relate the benefits and problems of RRI } \\
\text { to EC framework. }\end{array}$ & $\begin{array}{l}\text { Identify and respond to aspects of } \\
\text { EC framework that are specific to } \\
\text { project, area of enquiry, } \\
\text { stakeholder group. }\end{array}$ & $\begin{array}{l}\text { May be too prescriptive. May not } \\
\text { be accepted in other geographical } \\
\text { regions. May narrow scope and } \\
\text { constrain innovation or may create } \\
\text { confusion due to contradictions. } \\
\text { May lead to superficial or } \\
\text { 'tick-box' compliance. }\end{array}$ \\
\hline
\end{tabular}

Utilise the findings from the GREAT project empirical work to inform

12 development of the guidelines. This

will not be included in the guidelines themselves but a link to the project

May be too narrow in scope. website will be provided.

\section{Appendix A.2. The Requirements Tool—Requirements for Guidelines for RRI}

A tool such as this can be limited in its usefulness if it is unable to be effective beyond its original purpose. Validation of the guidelines themselves was enabled when they were adopted within another EU project (PROGRESSIVE) to guide its internal research processes. However, the requirements tool was not validated directly in this project. The built-in flexibility of the requirements tool, however, meant that it was designed to be suitable for use in different projects and contexts and its successful 
adoption and validation in a different context would indicate its usefulness for the future development of guidelines within different sectors.

\section{References}

1. Gray, D.J. Value-free Sociology: A Doctrine of Hypocrisy and Irresponsibility. Sociol. Q. 1968, 9, 176-185. [CrossRef]

2. Gouldner, A.W. Anti-Minotaur: The Myth of a Value-Free Sociology. Available online: https://heinonline.org/ HOL/P?h=hein.journals/socprob9\&i=209 (accessed on 18 April 2019).

3. Bernal, J.D. The Social Function of Science; Stephen Austin and Sons: Hertford, UK, 1939.

4. Douglas, H. Science, Policy, and the Value-Free Ideal; University of Pittsburgh Pre: Pitsburg, PA, USA, 2009.

5. Harley, J.B. Can there be a cartographic ethics? Cartogr. Perspect. 1991, 9-16. [CrossRef]

6. Funtowicz, S.; Ravetz, J.K. Post-normal science. In Companion to Environmental Studies; Routledge in Association with GSE Research: Abingdon, UK, 2018; Volume 443, pp. 443-447.

7. Lacey, H. Is Science Value Free?: Values and Scientific Understanding; Routledge: London, UK, 2005.

8. Kincaid, H.; Dupré, J.; Wylie, A. Value-Free Science: Ideals and Illusions? Oxford University Press: Oxford, UK, 2007.

9. Proctor, R.N.; Proctor, R. Value-Free Science?: Purity and Power in Modern Knowledge; Harvard University Press: Cambridge, MA, USA, 1991.

10. Tsui, A. Reflections on the so-called value-free ideal: A call for responsible science in the business schools. Cross Cult. Strateg. Manag. 2016, 23, 4-28. [CrossRef]

11. Kourany, J.A. Philosophy of Science after Feminism; Oxford University Press: New York, NY, USA, 2010.

12. Brown, M.J. The source and status of values for socially responsible science. Philos. Stud. 2013, 163, 67-76. [CrossRef]

13. Owen, J.R.; Kemp, D. Social licence and mining: A critical perspective. Resour. Policy 2013, 38, 29-35. [CrossRef]

14. Prno, J. An analysis of factors leading to the establishment of a social licence to operate in the mining industry. Resour. Policy 2013, 38, 577-590. [CrossRef]

15. Benn, S.; Edwards, M.; Williams, T. Organizational Change for Corporate Sustainability; Routledge: London, UK, 2018.

16. Stahl, B.; Obach, M.; Yaghmaei, E.; Ikonen, V.; Chatfield, K.; Brem, A. The Responsible Research and Innovation (RRI) maturity model: Linking theory and practice. Sustainability 2017, 9, 1036. [CrossRef]

17. Brand, T.; Blok, V. Responsible innovation in business: A critical reflection on deliberative engagement as a central governance mechanism. J. Responsib. Innov. 2019, 6, 4-24. [CrossRef]

18. Álvarez Jaramillo, J.; Zartha Sossa, J.W.; Orozco Mendoza, G.L. Barriers to sustainability for small and medium enterprises in the framework of sustainable development-Literature review. Bus. Strategy Environ. 2018, 28, 512-544.

19. Stahl, B. Responsible research and innovation: The role of privacy in an emerging framework. Sci. Publ. Policy 2013, 40. [CrossRef]

20. Von Schomberg, R. Prospects for technology assessment in a framework of responsible research and innovation\&nbsp. In Technikfolgen Abschätzen Lehren; Dusseldorp, M., Beecroft, R., Eds.; VS Verlag für Sozialwissenschaften: Berlin, Germany, 2012; pp. 39-61.

21. Stilgoe, J.; Owen, R.; Macnaghten, P. Developing a framework for responsible innovation. Res. Policy 2013, 42. [CrossRef]

22. Edelenbos, J.; Klijn, E. Managing stakeholder involvement in decision-making: A comparative analysis of six interactive processes in The Netherlands. J. Public Adm. Res. Theory 2006, 16, 417-446. [CrossRef]

23. Envision2030: Goal 16. Available online: https://www.un.org/development/desa/disabilities/envision2030goal16.html (accessed on 5 April 2019).

24. Envision2030 Goal 17. Available online: https://www.un.org/development/desa/disabilities/envision2030goal17.html (accessed on 5 April 2019).

25. Moffat, K.; Lacey, J.; Zhang, A.; Leipold, S. The social licence to operate: A critical review. For. Int. J. For. Res. 2016, 89, 477-488. [CrossRef] 
26. Dare, M.; Schirmer, J.; Vanclay, F. Community engagement and social licence to operate. Impact Assess. Proj. Apprais. 2014, 32, 188-197. [CrossRef]

27. Hall, N.; Lacey, J.; Carr-Cornish, S.; Dowd, A. Social licence to operate: Understanding how a concept has been translated into practice in energy industries. J. Clean. Prod. 2015, 86, 301-310. [CrossRef]

28. Boutilier, R.G. Frequently asked questions about the social licence to operate. Impact Assess. Proj. Apprais. 2014, 32, 263-272. [CrossRef]

29. Faucheux, S.; Combe, C.G.; Kuszla, C.; O'Connor, M. Social Costs of Non-Responsible Research. In Responsible Organizations in the Global Context; Springer: Berlin, Germany, 2019; pp. 199-219.

30. Holbrook, J.B. Designing responsible research and innovation to encourage serendipity could enhance the broader societal impacts of research. J. Responsib. Innov. 2019, 6, 84-90. [CrossRef]

31. Albareda, L.; Hajikhani, A. Innovation for Sustainability: Literature Review and Bibliometric Analysis. In Innovation for Sustainability; Springer: Berlin/Heidelberg, Germany, 2019; pp. 35-57.

32. Ferri, F.; Dwyer, N.; Raicevich, S.; Grifoni, P.; Altiok, H.; Andersen, H.T.; Laouris, Y.; Silvestri, C. Governance and Sustainability of Responsible Research and Innovation Processes: Cases and Experiences; Springer: Berlin/Heidelberg, Germany, 2018.

33. Lubberink, R.; Blok, V.; van Ophem, J.; Omta, O. Responsible innovation by social entrepreneurs: An exploratory study of values integration in innovations. J. Responsib. Innov. 2019. [CrossRef]

34. Responsible Research \& Innovation-Horizon 2020-European Commission. Available online: /programmes/ horizon2020/en/h2020-section/responsible-research-innovation (accessed on 11 December 2018).

35. Framework for Responsible Innovation. Available online: https://epsrc.ukri.org/research/framework/ (accessed on 25 March 2019).

36. Silva, L.M.D.; Bitencourt, C.C.; Faccin, K.; Iakovleva, T. The Role of Stakeholders in the Context of Responsible Innovation: A Meta-Synthesis. Sustainability 2019, 11, 1766. [CrossRef]

37. Limson, J. Putting responsible research and innovation into practice: A case study for biotechnology research, exploring impacts and RRI learning outcomes of public engagement for science students. Synthese 2018. [CrossRef]

38. GREAT. Available online: http://www.great-project.eu/ (accessed on 7 February 2019).

39. Universal Design for Learning at DMU. Available online: https://www.dmu.ac.uk/about-dmu/news/2017/ april/dmu\T1\textquoterights-sector-leading-support-for-students-wins-high-praise.aspx (accessed on 16 April 2019).

40. Disabled Students' Allowances: Written Statement-HCWS347. Available online: https: //www.parliament.uk/publications/written-questions-answers-statements/written-statement/Commons/ 2015-12-02/HCWS347 (accessed on 8 April 2019).

41. Rose, D.H.; Meyer, A. Teaching Every Student in the Digital Age: Universal Design for Learning; Association for Supervision and Curriculum Development: Alexandria, VA, USA, 2002.

42. Timmermans, J.; Stahl, B. Annual Report on the Main Trends of SiS in Particular the Trends Related to RRI. Available online: http://www.great-project.eu/research/deliverables (accessed on 8 April 2019).

43. Pelle, S.; Reber, B. The Theoretical Landscape. Available online: http://www.great-project.eu/research/ deliverables (accessed on 8 April 2019).

44. Lenoble, J.; Maesschalck, M. Toward a Theory of Governance: The Action of Norms; Kluwer Law International: Alphen aan den Rijn, The Netherlands, 2003.

45. Stahl, B.C. Responsible research and innovation in information systems. Eur. J. Inf. Syst. 2012, 21, $207-211$. [CrossRef]

46. Pellizzoni, L. Responsibility and Environmental Governance. Environ. Polit. 2004, 13, 541-565. [CrossRef]

47. Iordanou, K. Involving Patients in Research? Responsible Research and Innovation in Small-and Medium-Sized European Health Care Enterprises. Camb. Q. Healthc. Ethics 2019, 28, 144-152. [CrossRef]

48. Nulli, M.; Stahl, B. RRI in Higher Education. Orbit J. 2018, 1. [CrossRef]

49. Gurzawska, A.; Mäkinen, M.; Brey, P. Implementation of Responsible Research and Innovation (RRI) Practices in Industry: Providing the Right Incentives. Sustainability 2017, 9, 1759. [CrossRef]

50. Wilford, S.H. What is required of requirements? A first stage process towards developing guidelines for responsible research and innovation. Sigcas Comput. Soc. 2015, 45, 348-355. [CrossRef]

51. Bardone, E.; Lind, M. Towards a phronetic space for responsible research (and innovation). Life Sci. Soc. Policy 2016, 12, 5. [CrossRef] 
52. Coenen, C.; Grunwald, A. Responsible research and innovation (RRI) in quantum technology. Ethics Inf. Technol. 2017, 19, 277-294. [CrossRef]

53. Germonprez, M.; Hovorka, D.S. Member engagement within digitally enabled social network communities: New methodological considerations. Inf. Syst. J. 2013, 23, 525-549. [CrossRef]

54. Freeman, R.E. Strategic Management: A Stakeholder Approach; Cambridge University Press: London, UK, 2010.

55. Gandy, R.; Wilford, S. End of life services: Public and patient involvement. Br. J. Healthc. Manag. 2012, 18, 144-151. [CrossRef]

56. Wilford, S. First Line Steps in Requirements Identification for Guidelines Development in Responsible Research and Innovation (RRI). Syst. Pract. Action Res. 2018, 31, 539-556. [CrossRef]

57. Wilford, S.H.; Fisk, M.; Stahl, B. Guidelines for Responsible Research and Innovation; Centre for Computing and Social Responsibility, De Montfort University: Leicester, UK, 2016.

58. Jirotka, M.; Grimpe, B.; Stahl, B.; Eden, G.; Hartswood, M. Responsible research and innovation in the digital age. Commun. ACM 2017, 60,62-68. [CrossRef]

59. Wilford, S.; Timmermans, J.; Grimpe, B.; Jirotka, M. Requirements for Guidelines. Available online: http://www.great-project.eu/research/deliverables (accessed on 8 April 2019).

60. Responsible Innovation Compass. Available online: https://innovation-compass.eu/ (accessed on 5 February 2019).

61. Progressive Standards around ICT for Active and Healthy Ageing. Available online: https:// progressivestandards.org/ (accessed on 5 February 2019).

62. Krueger, R.; Casey, M. Focus Group: A Practical Guide for Applied Research; Public Understanding of Scienc; Sage Publications: Singapore, 2000.

63. AnonymousCAST: Center for Applied Special Technology. Choice Rev. Online 2014, 51, 5146. [CrossRef]

64. Rose, D. Universal design for learning. J. Spec. Educ. Technol. 2000, 15, 45-49. [CrossRef]

65. Pettit, I.; Hall, R. Change Management in Ukhe-A Case Study of a Large-Scale Multimedia Roll-Out; De Montfort University: Leicester, UK, 2018.

66. Brown, J.B.; Hall, R.; Lishman, R.; Rushworth, J.; Snape, J.R. Designing for Difference: Lessons from a Cross-Disciplinary Implementation of Universal Design for Learning; University of Utah: Salt Lake City, UT, USA, 2017.

67. Black, R.D.; Weinberg, L.A.; Brodwin, M.G. Universal design for learning and instruction: Perspectives of students with disabilities in higher education. Except. Educ. Int. 2015, 25, 1-16.

68. Funtowicz, S.; Shepherd, I.; Wilkinson, D.; Ravetz, J. Science and governance in the European Union: A contribution to the debate. Sci. Public Policy 2000, 27, 327-336. [CrossRef]

69. Wilford, S.H.; Fisk, M.; Stahl, B.C. Guidelines for Responsible Research and Innovation. GREAT (Governance of Responsible Innovation) FP7 Grant Agreement No: N³21480; European Commission 2016. Available online: http://www.great-project.eu/Deliverables10 (accessed on 8 April 2019). 